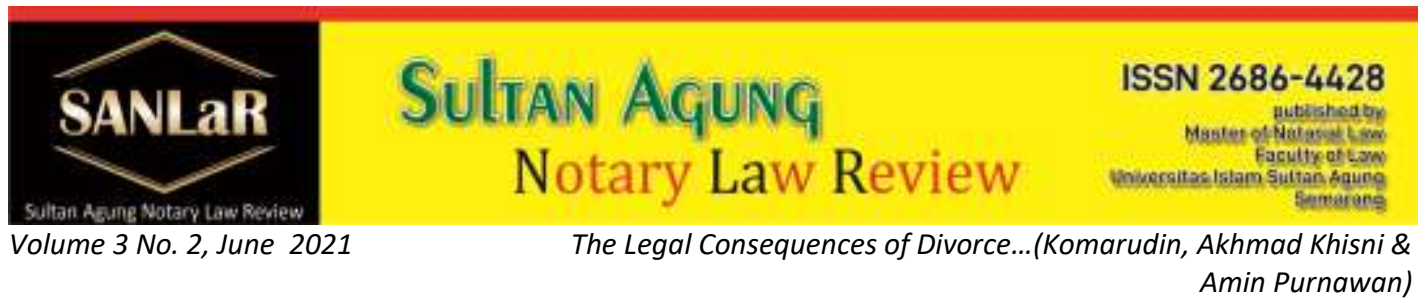

\title{
The Legal Consequences of Divorce on Joint Assets in the Religious Courts
}

\author{
Komarudin $^{*}$, Akhmad Khisni**), Amin Purnawan ${ }^{* * *}$ ) \\ *) Faculty of Law, Universitas Islam Sultan Agung (UNISSULA) Semarang, E-mail: \\ nanangkomarudin324@gmail.com
}

${ }^{* *)}$ Faculty of Law, Universitas Islam Sultan Agung (UNISSULA) Semarang, E-mail: khisni@unissula.ac.id

${ }^{* * *}$ Faculty of Law, Universitas Islam Sultan Agung (UNISSULA) Semarang, E-mail: amin.p@unissula.ac.id

\begin{abstract}
The purpose of this study is to find out and explain the legal consequences of divorce on joint property in religious courts. To find out and explain the obstacles due to divorce law on joint property in religious courts. The method used by the researcher is Juridical Empirical (socio-legal research) and the specifications in this study are descriptive analytical. Based on the results of the study that resulting in marital property controlled by the husband without the consent of the ex-wife cannot/is not allowed to sell or transfer the property without the consent of the ex-wife. The obstacle: shows that there is still a lack of public understanding of the applicable legal provisions governing assets in marriage. Economic factors. Factors of objects or objects (Joint Asset or Gono-gini property). The responsibility factor of the parties (husband and wife). The solution: the need for legal counseling to the community and the prospective brides who will carry out the marriage. The settlement can be through the village head, but if it cannot be resolved through the village head then through the court institution by attaching a certificate of incapacity (prodeo). The settlement of one of the selling parties must be reduced by the distribution of the value of the price of the goods sold. The settlement in this case is that the collateralized object is confiscated and auctioned by the bank as the creditor who provides the debt facility.
\end{abstract}

Keywords: Legal; Consequences; Divorce; Joint Assets.

\section{Introduction}

It has become human nature, that basically humans have a desire to live 
together with each other. Since birth, humans have been equipped with the instinct to live together with other people. Humans always need each other, because humans are social creatures (Zoon Politicoon) according to Aristotle. One form of manifestation of the urge to live together is family. In society, family life is the core of the relationship between humans, so that the basis of social life which ultimately forms a nation and state. ${ }^{1}$

Continuing in marriage is one of the cultures whose settings follow the development of human culture in the social order. Marriage has existed since a simple society which is maintained by community members and traditional community leaders and religious leaders. Developments in marriage culture and the rules that apply to a society or to a nation will not be separated in the form of cultural and environmental influences wherever the community is exist and socialize with the community. ${ }^{2}$

In the interests of mankind at large, marriage is a way to maintain the continuity of the species through legal and responsible offspring. So marriage is a way of realizing peace of mind and peace of mind, maintaining self-purity from heinous acts as well as enjoyment, happiness in life, as well as a means to fortify oneself so as not to fall into the abyss of humiliation. The purpose of marriage in Islam is as the backbone of the formation of a family to meet the demands of human nature, to relate between men and women in order to create a happy family on the basis of love and affection, to obtain legitimate offspring in society by following the provisions stipulated in the law regulated by sharia. ${ }^{3}$

According to Act No. 1 of 1974 Article 1 marriage is an inner and outer bond between a man and a woman as husband and wife with the aim of forming a happy and eternal family based on God Almighty. ${ }^{4}$

Joint assets exist at the time of the marriage, while innate assets are obtained before the marriage takes place, but in reality many families in Indonesia do not record their joint assets. In a marriage that is still new, the division of inheritance and joint property is still clear, but at an old age of marriage, it is difficult to explain in detail one by one.

The objectives to be achieved from this research are as follows:

To find out and explain the legal consequences of divorce on joint property in religious courts and its practice in the community.

To find out and explain the constraints resulting from divorce law on joint property in religious courts and their practice in the community and their

\footnotetext{
${ }^{1}$ Ahmad Rofiq, 2003, Hukum Islam di Indonesia, cetakan keenam, Rajawali Pers, Jakarta, p.5

${ }^{2}$ Hilman Hadikusuma, 2007, Hukum Perkawinan Indonesia Menurut: Perundangan, Hukum Adat, Hukum Agama, Mandar Maju. Bandung, p. 1

${ }^{3}$ Soemiyati, 2007, Hukum Perkawinan Islam dan Undang-Undang Perkawinan, cetakan keenam, Liberty, Yogyakarta, p. 12.

${ }^{4}$ Ahmad Azhar Basyir, 2007, Hukum Perkawinan Islam, cetakan kesebelas, UII Press, Yogyakarta, p. 2
} 
solutions.

\section{Research Methods}

The research approach used is a normative juridical approach. ${ }^{5}$ The research is also supported by empirical data "empirical juridical approach method is used to study legislation"6. The research specifications used in this study are descriptive analytical. ${ }^{7}$ The sources and types of data in this study are primary data. And secondary data obtained from literature studies related to the theory of justice and balance.

\section{Results and Discussion}

\subsection{Knowing Shared Assets or Gono Gini Assets in Islam}

Is there any in Islamic law (Al-Qur'an, Sunnah, and Figh) know about the existence of joint property or property like this? In the Qur'an, Sunnah and Figh there is no shared property between husband and wife, but in Islam there is a separation of property between husband and wife.

"And for you (husbands) half of the property left by your wives, if they do not have children. If your wives have children, then you will get a quarter of the property left by them after their will has been fulfilled or (and) the debt has been paid. Wives get a quarter of what you leave if you have no children. If you have children, then the wives get one-eighth of the property you left after fulfilling your will or (and) after paying your debts. If a person dies, both male and female, who does not leave a father and does not leave children, but has a brother (one mother only) or a sister (only one mother), then for each of the two types of siblings one-sixth treasure. But if the mother's brothers are more than one, then they are partners in the third one, after fulfilling the will made by him or after paying the debt by not giving harm (to the heirs). (Allah has determined that as) the true Shari'ah from Allah, and Allah is All-Knowing, Most Forbearing" (Surah An-Nisa'-12).

In the verse above, it is not known that there is a mixture of assets (gono gini) of husband and wife, but it is explained that each husband and wife have rights to their respective assets.

\footnotetext{
${ }^{5}$ Bambang Waluyo, 1996, Metode Penelitian Hukum, Sinar Grafika, Jakarta, p.13

${ }^{6}$ Ulber Silalahi, 2009, Metode Penelitian Sosial, Refika Aditanam, Bandung, p. 29

${ }^{7}$ Sunaryati Hartono, 1994, Penelitian Hukum Indonesia Pada Akhir Abad ke-20, Alumni, Bandung, p. 101.
} 
In addition to the arguments from the Qur'an and the hadith mentioned above, the Muslims of the Fuqaha' group since the time of the Prophet until now have agreed that a husband is obliged to provide a living for his wife for the survival of the household.

Livelihood is the husband's obligation to his wife in material form, because the word livelihood itself has a material connotation.[6]While obligations in the form of non-material, such as satisfying the wife's sexual needs are not included in the meaning of living, even though the husband does it to his wife. The word that has been used inappropriately for this purpose is inner livelihood while in material form it is called outer livelihood. In the proper language of this livelihood there is neither outwardly nor inwardly. There is only a living, which means things that are outward or material.

The obligation to provide a living by a husband to his wife which applies in figh is based on the principle of separation of property between husband and wife. This principle follows the line of thought that the husband is a seeker of sustenance; The sustenance that he has obtained becomes his full right and henceforth he has the position of being the provider of the breadwinner. On the other hand, the wife is not a sustenance seeker and to fulfill her needs she is the recipient of the breadwinner. Therefore, the obligation of maintenance is irrelevant in a community that follows the principle of combining property in the household.

In positive Indonesian law, the issue of living or fulfilling family needs has also been regulated and declared to be the husband's obligation. This is in accordance with Act No. 1 of 1974, article 34 paragraph (1) and confirmed by KHI Article 80 paragraph (4). The existence of a living certainly has a very large influence and function in fostering a happy, peaceful and prosperous family. Not being fulfilled at all or not having enough income can result in a marital crisis that can lead to divorce. 
The existence of rules regarding living in the KHI and Act No. 1 of 1974 raises a problem when it is associated with the recognition of joint property by husband and wife when a divorce occurs. By looking at Article 1 letter (f) of the KHI and Article 35 paragraph (1) of Act No. 1 of 1974 shows that the qualification used in formulating joint property is to use a legal marriage period. As long as the property is obtained in a legal marriage, it becomes joint property by referring to the provisions of joint property in the KHI and Act No. 1 of 1974. However, both of them provide a limitation that the assets obtained as a result of gifts and inheritance become their respective personal assets as long as it is intended for that purpose (Article 36 paragraph 1).

The provisions for joint property have been regulated in $\mathrm{KHI}$ articles 85-97, as well as in Act No. 1 of 1974 concerning Marriage, articles 35-37 the provisions of joint property in the KHI and Act No. 1 of 1974 is inseparable from the reality of the Indonesian people regarding joint property with various terms. The term joint property in East Java is called gono-gini, in Minangkabau it is called treasure Surang, in Banda Aceh it is called hareuta-seuhareukat.

If observed, the provisions regarding joint assets and the husband's obligation to provide a living in the $\mathrm{KHI}$ and Act No. 1 of 1974 shows that the husband who has the obligation to provide a living must accept a joint property regulation which has the consequence of dividing joint property with an equal share, and the use of joint property must obtain the consent of the husband and wife. Another problem that arises is regarding the implementation of the husband's obligation to provide a living, including in joint or independent assets. So that these two rules can create legal loopholes that can damage the principles of legal certainty and community justice. 
According to article 35 of Act No. 1 of 1974 concerning Marriage, joint assets of husband and wife only include assets obtained by husband and wife during the marriage. This means that assets acquired during the grace period between the inauguration of the marriage until the marriage is terminated, either due to death (divorce) or due to divorce.

The concept of joint property and all its provisions is not found in the study of figh (Islamic law). The problem of joint property is a legal issue that has not been touched or thought of (ghoir al-mufakkar) by previous figh scholars, because the issue of joint property has just emerged and is widely discussed in modern times. In the study of classical Islamic fiqh, the issues that are often expressed are the problems of managing a living and the law of inheritance. These two things have caught the attention of classical figh studies.

In general, Islamic law (Qur'an, Sunnah, and Fiqh) does not see the existence of shared property. Islamic law views the separation between husband and wife's assets. What is produced by the husband is his property, and vice versa, what is produced by the wife is his property. As an obligation, the husband gives part of his wealth to his wife in the name of living, which is then used by the wife for her household needs. There is no combination of assets, except in the form of syirkah, for which it is carried out in a special contract for syirkah. Without the contract, the assets remain separate.

If in the marriage contract assembly an agreement is made for the merger of assets, what is obtained by the husband or wife becomes joint property, then there is joint property in the marriage. Thus the occurrence of a marriage contract does not automatically occur joint property. However, joint property in marriage can occur and is only possible in two forms, namely: First, the existence of a syirkah contract between husband and wife, whether made during the 
marriage contract or after. Second, there is an agreement made for that at the time of the marriage contract.

According to M. Yahya Harahap, that the perspective of Islamic law regarding joint property is in line with what Muhammad Shah said that joint livelihoods with husband and wife should be included in the rubu' mu'amalah, but it was not discussed specifically. This may be because in general, the authors of fiqh books are Arabs who generally do not know how to work together with husband and wife. What is known is the term syirkah or sharing.

Khoiruddin Nasution stated that Islamic law regulates the system of separating husband and wife assets as long as the person concerned does not specify otherwise (not specified in the marriage agreement). Islamic law provides leeway for married couples to make a marriage agreement which will eventually be legally binding.

Ahmad Azhar Basyir is of the opinion that Islamic law provides for each partner, either husband or wife, to own property individually which cannot be disturbed by each party. The husband who receives gifts, inheritance, and so on has the right to fully control the property he receives without the wife's interference. The opposite is also true. Thus the innate property they had before the marriage became the property of each married couple.

From the two expert views above, it can be seen that the Islamic provisions that separate the assets of husband and wife will actually make it easier for husband and wife in the event of a divorce process because the process is not complicated and convoluted. Based on this, the problem of joint property is not clearly and explicitly mentioned in Islamic law, so it is open for Islamic jurists to carry out ijtihad with a qiyas / analogy approach. 
Joint assets can be make Qiyas as syirkah because it can be understood that the wife can also be counted as a partner (shareholder) who works, even though she does not participate in the work in the true sense. What is meant is the wife's work such as taking care of the household, cooking, washing, caring for children and other domestic needs.

Joint assets are defined as assets produced by a husband and wife during the marriage. So, joint property is categorized as syirkah mufaawadhah or syirkah abdaan. It is said to be syirkah mufaawadlah because the partnership between husband and wife in joint property is unlimited, whatever they produce during their marriage is included in the joint property. Inheritance and giving are exceptions. While joint property is referred to as syirkah abdaan because most of the husband and wife in Indonesian society work together to make a living for their family.

In mu'amalah figh, syirkah abdaan or syirkah mufaawadlah is part of syirkah 'uqud. Syirkah 'uqud is a partnership that requires a contract between its members. Profits are shared based on the agreement of both parties.

From the explanation above, it can be concluded that joint property is a form of syirkah as previously explained by Amir Syarifuddin. Because it implies a form of cooperation or sharing between husband and wife. It's just that not in the form of syirkah in general which is business or cooperation in business activities, syirkah in joint property is a form of cooperation between husband and wife to build a sakinah family, which is filled with mawaddah and warahmah, including property in marriage.

Furthermore, when viewed from the provisions of the marriage law, joint marital assets are detailed by $\mathrm{KHI}$ in articles 85 to 97 . Meanwhile, with regard to the 
personal assets of husband and wife brought into the household and assets obtained during the marriage, which are determined together with the syirkah contract or through an agreement in marriage, regulated in Chapter VII Articles 35, 36, and 37 of the Marriage Law.

If it is understood further, it can be concluded that this joint property consists of: the results and income of the husband, the results and income of the wife, and the results and income from the personal property of the husband or wife, even though the principal assets are not included in the joint property provided that all of them are obtained as long as marriage. Meanwhile, personal property is property that is already owned by the husband or wife at the time of the marriage and is not included in the joint property unless they have agreed otherwise. These personal assets include: husband/wife assets, husband/wife gifts, and husband/wife inheritance.

The position of joint property in Indonesian marriage law is regulated in Article 35 and Article 36 of Act No. 1 of 1974 concerning Marriage which states that property acquired during marriage becomes joint property and can be used with the consent of both parties, while inheritance, gifts, and inheritance remain under the control of each and are full rights as long as the parties do not determine otherwise.

Therefore, joint property is a marital property that is owned by husband and wife jointly. Namely, movable or immovable property obtained since the establishment of a legal husband and wife relationship, which can be used by husband and wife to finance their living needs and their children, as a unified whole in the household. Therefore, joint property is property obtained during the marriage bond and without questioning whose name is registered. The beginning of the formation of joint property in this marriage, because there is 
still the principle of each husband and wife to have the right to control their own property, as was the case before they become husband and wife, except for joint property which is of course jointly controlled.

Based on the provisions of Articles 35 and 36 above, Act No. 1 of 1974 does not adhere to the principle of mixing or unification of assets due to marriage, so that the assets, gifts, and inheritance of husband and wife are separated and remain under the control of each and are full rights, as long as the parties do not determine otherwise through a marriage agreement. Meanwhile, the joint assets obtained during the marriage bond become the joint property of husband and wife, without questioning who actually drained their efforts to obtain the property and is jointly controlled and managed and each husband and wife are joint owners of the joint property.

All income or income of husband and wife during the marriage bond, other than original assets and/or gifted assets that follow original assets are joint assets. It doesn't matter whether the wife is actively working or not, even though the wife only stays at home taking care of the household and children, while the husband works alone. When the marriage breaks up, the joint property is regulated according to their respective laws. What is meant by the respective laws are religious law, customary law, and the Civil Code.

The above provisions are different from Article 119 of the Civil Code which states that from the moment the marriage takes place, according to the law there is a total joint property between husband and wife, as long as there are no other provisions in the marriage agreement. The joint property, as long as the marriage is running, may not be abolished or changed with an agreement between husband and wife. Thus, since the start of the marriage, there has been a mixture of the wealth of the husband and the wealth of the wife (algehele gemeenschap 
van goederen) if an agreement is not made. This situation continues and cannot be changed again during the marriage. If people want to save from these regulations, then their wishes must be put in a marriage agreement (huwelijksvoorwaarden). Such an agreement must be made before the marriage is closed in front of the Civil Registration Officer and must be placed in a notarial deed. The law requires that the state of wealth in a marriage is fixed, in order to protect the interests of third parties. When a divorce occurs, this joint property is divided in half between husband and wife without the need to pay attention to which party the goods were originally obtained from.

In the Compilation of Islamic Law (KHI) in article 85 which reads: "the existence of joint property in marriage does not rule out the possibility of property belonging to each husband or wife." From this article it can be concluded that the assets obtained by a husband and wife because of their business are joint assets, whether they work together or only the husband works. While the wife only takes care of the household and their children at home. When they are bound by a marriage agreement as husband and wife, then everything becomes united, both marital property and children. It does not need to be accompanied by syirkah, because marriage with a Kabul consent and if it meets other requirements is considered syirkah between the husband and wife.

Yahya Harahap explained that if you look at the history of the formation of joint property, there has been a development of customary law on joint property based on the condition that the wife physically participates in helping her husband's work. If the wife does not physically participate and assist her husband in finding property, then the old customary law assumes that joint property has never been formed in marriage. In the course of further history, this opinion received strong criticism from various legal experts in line with the development of the view of women's emancipation and the flow of globalization in all fields. In 
response to this criticism, there was a shift in the conception of new legal values, the climax of which was in 1950 when a court product was born which overrides the requirement that the wife be physically active in realizing joint property.

From the description above, it is clear that the law has determined a legal consequence of the intermediary of the marriage contract with property ownership, namely the determination of the association. By law, two husbands and wives are seen as a couple who are mu'amalat to conduct syirkah. Such a view is not wrong, because the Qur'an and Hadith do not explicitly regulate this matter, therefore, it is a matter of ijtihadi and is supported by a real benefit, namely legal certainty for family assets which one day there will be a possibility divided due to the death or divorce of one of them. In addition, strengthening this view is the command of mu'asyarah bil ma'ruf and life to help each other between husband and wife. Without real consent and Kabul,

The existence of joint property in marriage is solely intended to meet the needs of husband and wife together and their children, so that the use of joint property must be with the mutual consent of husband and wife, cannot be controlled unilaterally and arbitrarily. Therefore, if there is a suspicion or indication of an act of abuse by one of the parties between the husband or wife, by transferring to another party, wasting or embezzling the joint property, then the law provides a guarantee that the integrity of the joint property in the marriage remains intact protected and maintained through "confiscation" of the application submitted by the husband or wife as well as interested parties to the court.

The husband has an obligation to meet the economic demands of the family. To form an ideal family, full of happiness and prosperity, it must be supported by the fulfillment of the needs of each party in a family. The needs of food, clothing, shelter and daily needs of a wife, children and husband must be considered. 
Neglect of material needs is the same as leaving open opportunities for rifts in a family.

The nash provisions indicate that the economic burden of the family is borne by the husband. The husband is obligated to provide for his wife and children according to their eligibility and level of ability. Husbands must try as much as possible to get results that can meet the economic needs of the family. In addition, the role of a wife is needed to provide support to her husband in seeking sustenance. Because to get sustenance, humans must work hard and exert all power and effort. And herein lies a wife to continue to encourage her husband to work optimally and obtain optimal results as well.

With the emergence of the concept of joint property in the $\mathrm{KHI}$ and Act No. 1 of 1974, automatically the classical figh concept can no longer be carried out for the husband, in the sense that living is no longer the obligation of a husband only, but also the obligation of the wife. Both of these regulations (KHI and Act No. 1 of 1974) state that property acquired during marriage becomes joint property. Thus, through a simple thought, the income earned by the husband during marriage is joint property. The consequence that arises for joint property is that legal action on the property must be approved by both parties because both have rights to the property.

To be clear, according to the author's opinion, there are at least three juridical consequences that will occur when the concept of joint property is applied in the family of Muslim communities around the world, especially Indonesia which clearly stipulates it in the UUP and $\mathrm{KHI}$, namely:

In the Compilation of Islamic Law (KHI) it has been regulated regarding joint assets or gono-gini assets in Chapter XIII concerning Wealth in Marriage, from 
Article 85 to Article 97 binding the rules of the Compilation of Islamic Law (KHI) Article 97 which regulates joint property

\section{Article 97}

"Each widow or widower is entitled to one-half of the joint property as long as it is not stipulated otherwise in the marriage agreement"

Islam recognizes the holding of peace if the ex-husband and ex-wife are in disagreement, especially regarding the issue of joint property. Ideally, when a husband and wife are divorced and have problems with joint property or gonogini, there are two options for resolving the dispute, namely:

a. Peace according to Islamic law

b. Sharing of Shared Assets in the Religious Courts

Peace has a high degree and should be prioritized by Muslims, as the word of Allah SWT regarding peace as follows:

"There is no good in most of their whispers, except the whispers of those who command (humans) to give alms, or to do ma'ruf, or to make peace between people. And whoever does this seeking the pleasure of Allah, then We will give him a great reward." [Surah An-Nisa' 4:114]

In making peace regarding joint property in Islam, a complete understanding of the principles of justice in Islam is needed. Given that in Islam there is no known joint property, it will be very difficult to be able to resolve disputes regarding the joint property of a divorced husband and wife. However, if both follow (the Qur'an, Sunnah, and Fiqh) and are facilitated by a cleric or cleric who 
understands peace and property according to Islam and the obedience of the two disputing parties, peace is very likely to be achieved.

In addition to the above options regarding peace in Islam without being involved with the Compilation of Islamic Law in force in Indonesia, Parties in dispute regarding joint property may file a lawsuit regarding the Distribution of Joint Assets in the Religious Courts. In the rules of the Compilation of Islamic Law in Article 97, it has been regulated that each widow and widower has the right of half a share (50:50) of the joint property obtained during the marriage. Of course, not all assets can be divided or categorized as joint property. Article 87 of the $\mathrm{KHI}$ also recognizes innate assets which cannot specifically be categorized as joint assets.

\section{Article 87}

(1) The innate property of each husband and wife and the assets obtained by each as a gift or inheritance are under their respective control, as long as the parties do not specify otherwise in the marriage agreement.

In the Compilation of Islamic Law, it is also known about joint debt, of course, joint debt as regulated in Article 93 of the Compilation of Islamic Law stipulates that not all debts of a wife or husband can be categorized as joint debt.

\section{Article 93}

Accountability for the debts of the husband or wife is borne by their respective assets.

Accountability for debts carried out for the benefit of the family is borne by joint assets. 
If the joint property is not sufficient, it is charged to the husband's property.

If the husband's property does not exist or is sufficient, it is charged to the wife's property

After knowing what the joint assets and joint debts are, then the joint assets can be distributed by filing a lawsuit for the distribution of joint assets in the Religious Courts.

\subsection{The Legal Consequences of Divorce on Joint Assets in the Religious Courts}

H. Hilman Hadikusuma explained in the book "Indonesian Marriage Law According to: Customary Law Religious Law" (p. 189), the legal consequences relating to joint property based on Article 37 of this Marriage Law are left to the divorced parties regarding which law and what law will apply, and if there is no agreement between the ex-husband and wife, the judge can consider according to a reasonable sense of justice. So, the consequences of a divorce on joint property for each person can vary, depending on what law and which will be used by the parties to regulate joint property. ${ }^{8}$

The religious court which is a judiciary for Muslims to decide all civil matters of Muslims, one of which is the issue of inheritance, must be able to answer and decide all these questions fairly for Muslims who of course follow all developments in Islamic inheritance law in Indonesia in the hope that there will be no turmoil in society. ${ }^{9}$

${ }^{8}$ Hilman Hadikusuma, 1963, Hukum Perkawinan Adat, Alumni, Bandung, p. 189

${ }^{9}$ Syarief Husien, Akhmad Khisni, Hukum Waris Islam Di Indonesia (Studi Perkembangan Hukum Kewarisan Dalam Kompilasi Hukum Islam Dan Praktek Di Pengadilan Agama), Vol 5 No 1 March 2018, Jurnal Akta 
Marriage is universal and not limited by skin color, race and nationality. It is not surprising that the number of mixed marriages continues to increase, including in Indonesia. The definition of marriage is regulated in Article 1 of Act No. 1 of 1974 concerning Marriage (hereinafter abbreviated as the Marriage Law) which applies nationally, which states: "Marriage is an outer and inner bond between a man and a woman as husband and wife with the aim of forming a happy family or household and eternal according to His Majesty. ${ }^{10}$

The Compilation of Islamic Law, a collection of Islamic legal materials written by articles totaling 229 articles, consists of three groups of legal materials, namely: Marriage Law (170 articles), Inheritance Law including wills and grants (44 articles) and Waqf Law (14 articles) plus one clause of the closing provisions applicable to the three legal groups. ${ }^{11}$

According to the provisions of article 38 of the Marriage Law, a marriage can be terminated due to (a) death, (b) divorce, (c) on the decision of the Court. Dissolution of marriage due to death is often referred to by the community as "divorce". Meanwhile, the dissolution of a marriage due to divorce has two names, namely "claimed divorce" and "Talak/divorce". The dissolution of the marriage due to the Court's decision is called "annulled divorce. ${ }^{12}$

If the marriage breaks up due to divorce, problems arise, among others, regarding the distribution of joint assets whose arrangements are according to

\footnotetext{
${ }^{10}$ Bella Arwinilita, Gunarto and Anis Mashdurohatun, Implementation of Deep Assets Separation Agreement of Indonesian Citizens Who Marriage with Foreign Citizens, Volume 3 No. 1, March 2021, Jurnal Sultan Agung Notary Law Review

${ }^{11}$ Nabilla Ayu Suraya, Akhmad Khisni and Munsharif Abdul Chalim, Research on Inheritance for Children from Sirri Marriage Based on the Compilation of Islamic Law, Volume 2 No. 4, December 2020, Jurnal Sultan Agung Notary Law Review

${ }^{12}$ Sukardi, 2016, "Kajian Yuridis Perjanjian Perkawinan Menurut Kitab Undang-Undang Hukum Perdata, Undang-Undang Nomor 1 Tahun 1974 dan Kompilasi Hukum Islam", Jurnal Khatulistiwa - Journal of Islamic Studies, Vol. 6, No. 1, p. 65.
} 
their respective laws, namely religious law, customary law, and other laws, meaning that joint assets are regulated according to their respective laws. This indicates that when a divorce occurs, the joint property acquired by a husband and wife during marriage can be regulated using different rules depending on variations in customary law or other laws outside customary law. ${ }^{13}$

It is best if the division of joint property is carried out fairly, so that it does not cause injustice between which is the right of the husband and which is the right of the wife. According to Erna Wahyuningsih and Putu Samawati, the method of obtaining joint property is as follows: The distribution of joint property can be submitted at the same time as filing for divorce by mentioning the joint property and evidence that the property was obtained during the marriage in "posita" (reason for filing a lawsuit). . The request for the distribution of assets is stated in the petitum (lawsuit). The distribution of joint property is filed after a divorce decision is made, which means filing a lawsuit over joint property. For those who are Muslim, a lawsuit over joint property is submitted to the religious court in the area where the wife lives. ${ }^{14}$

The Legal Consequences of Divorce on Joint Assets in the Religious Courts resulting in the marriage property controlled by the husband without the consent of the ex-wife cannot / is not allowed to sell or transfer the property without the consent of the ex-wife, because in the marital property there is still the wife's rights, as long as there is no permanent legal force.

If it is associated with the theory of justice, the legal consequences of divorce on joint assets in the religious courts are that justice is a type of distributive justice

\footnotetext{
${ }^{13}$ Evi Djuniarti, 2017, Hukum Harta Bersama Ditinjau Dari Perspektif Undang-Undang Perkawinan Dan KUHPerdata, Jurnal Penelitian Hukum DE JURE, Vol. 17 No. 4, p. 8

${ }^{14}$ Bernadus Nagara, 2016, Pembagian Harta Gono-Gini atau Harta Bersama Setelah Perceraian Menurut Undang-Undang Nomor 1 Tahun 1974, Lex Crimen, Vol. 5, No. 7, p. 2
} 
and corrective justice. Distributive justice according to Aristotle focuses on the distribution, honors, wealth, and other goods that are equally obtainable in society. Leaving aside the mathematical "proof", it is clear that what Aristotle had in mind was the distribution of wealth and other valuables based on the values prevailing among the citizens. A fair distribution may be a distribution that is in accordance with the value of its goodness, namely its value to society.

\subsection{Constraints Due to Divorce Law on Joint Assets in the Religious Courts}

Indonesian citizens who feel aggrieved because when they want to buy an apartment it cannot be done because of the refusal to buy from the developer because the buyer is married to a foreign citizen, which is regulated in Article 35 of the Marriage Law that assets acquired during the marriage become the property of the partnership, then in Article 35 of the Marriage Law. The UUPA states that only Indonesian citizens can have the same property rights. Because of that, applicants feel disappointed, disadvantaged and human rights have been deprived by their rules. ${ }^{15}$

Marriage is an inner and outer bond between a man and a woman as husband and wife to form a happy and eternal family based on the One Godhead. As an anticipation of the possibility of marriage failure is to enter into a marriage agreement by the prospective husband and wife. The marriage agreement for the Indonesian people is an unusual thing even though it has been regulated in the Marriage Law. The marriage agreement as regulated in Act No. 1 of 1974 concerning Marriage and the Compilation of Islamic Law Presidential Instruction Number 1 of 1991 can be used as a legal means to protect the rights and obligations of husband and wife when married life takes place. This marriage

\footnotetext{
${ }^{15}$ Wisda Rauyani Efa Rahmatika, Akhmad Khisni, Analisis Yuridis Atas Perjanjian Perkawinan Ditinjau Dari Undang-Undang No.1 Tahun 1974 Tentang Perkawinan Dan Implikasi Putusan MK NO.69/PUU-XIII/2015 Vol. 4 No. 3 September 2017, Jurnal AKta Unissula
} 
agreement must be made based on mutual consent and ratified by the marriage registrar, which ideally contains aspects of legal certainty, justice, and the usefulness of the marriage agreement made must not harm third parties as stipulated in Article 29 of Act No. 1 of 1974. Thus, third parties related to the rights of third parties receive legal protection, this is quite clearly regulated in the above provisions. So if the marriage agreement does not provide legal protection as specified in Article 2 paragraph (2), then by law the marriage agreement is null and void. ${ }^{16}$

Legal consequences arise because of a legal relationship, ${ }^{17}$ For example, marriage between a man (husband) and a woman (wife) is a legal relationship that gives rights and obligations to both parties. Legal consequences are also defined as the consequences given by law on an act of legal subjects.

The factors that become obstacles/obstacles in the implementation of the distribution of joint property due to divorce are:

a. From the community

b. From the Village Head's Office

From the results of research conducted by the author that the Divorce Constraints Against Joint Assets in the Religious Courts and the solutions, namely:

1) The existence of obstacles, as obtained from the results of the research above, shows that there is still a lack of public understanding of the applicable legal provisions governing property in marriage.

There is a need for legal counseling to the community and the prospective bride and groom who will hold a marriage regarding matters relating to marital property so that later husband and wife or the community will know what their rights are if in the future a divorce occurs.

\footnotetext{
${ }^{16}$ Firman Hidayat, Akhmad Khisni, Tinjauan Asas Kepastian Hukum, Keadilan, Dan Kemanfaatan Dalam Akta Perjanjian Kawin Yang Di Buat Oleh Notaris, Vol. 4 No. 4 December 2017, Jurnal Akta Unissula

${ }^{17}$ J.C.T. Simorangkir, 1972, Kamus hukum: oleh J. C. T. Simorangkir, Rudy T. Erwin dan J. T. Prasetyo Madjapahit, p. 6.
} 
2) Economic factors are often an obstacle for parties whose rights are violated, but are unable to finance them so that they cannot be resolved in court and the case becomes adrift.

In this case the settlement can be through the village head, but if it cannot be resolved through the village head then through the court institution by attaching a certificate of incapacity (prodeo).

1) The object or object (Joint Asset or Gono-gini property) in dispute is built on land belonging to his father-in-law.

In this case, the settlement of one of the selling parties must be reduced by the distribution of the value of the price of the goods sold.

2) The responsibility factor of the parties (husband and wife) who have debts to the bank, buy movable objects in installments such as cars, motorcycles, and others.

The settlement in this case is that the collateralized object is confiscated and auctioned by the bank as the creditor who provides the debt facility and if there is an excess of the remainder of the auction as payment for the debt, the remainder is divided between the divorced husband and wife. Meanwhile, the immovable property purchased in installments will be confiscated by the dealer or the institution that finances it.

Divorce constraints on joint property in religious courts and their solutions analyzed from the point of view using the balance theory that Article 30 and Article 31 of Act No. 1 of 1974 concerning Marriage explain the balance of obligations between husband and wife. As a result of the development of society, the development of law goes hand in hand. Judges are one of the factors in the formation of law, the Legislative Body determines the applicable regulations as general rules, while considerations in implementing concrete matters are left to the judge, as the holder of the Judicial power. 


\section{Closing}

The Legal Consequences of Divorce on Joint Assets in the Religious Courts resulting in marital property controlled by the husband without the consent of the ex-wife cannot / is not allowed to sell or transfer the property without the consent of the ex-wife, because in the marital property there is still the wife's rights, as long as there is no permanent legal force and the obstacle: shows that there is still a lack of public understanding of the applicable legal provisions governing assets in marriage. Economic factors. Factors of objects or objects (Joint Asset or Gono-gini property). The responsibility factor of the parties (husband and wife). The solution: the need for legal counseling to the community and the prospective brides who will carry out the marriage. The settlement can be through the village head, but if it cannot be resolved through the village head then through the court institution by attaching a certificate of incapacity (prodeo). The settlement in this case is that the collateralized object is confiscated and auctioned by the bank as the creditor who provides the debt facility.

\section{References}

Journals:

[1] Bella Arwinilita, Gunarto and Anis Mashdurohatun, Implementation of Deep Assets Separation Agreement of Indonesian Citizens Who Marriage with Foreign Citizens, Volume 3 No. 1, March 2021, Jurnal Sultan Agung Notary Law Review

[2] Bernadus Nagara, 2016, Pembagian Harta Gono-gini atau Harta Bersama Setelah Perceraian Menurut Undang-Undang Nomor 1 Tahun 1974, Lex Crimen, Vol. 5, No. 7

[3] Evi Djuniarti, 2017, Hukum Harta Bersama Ditinjau Dari Perspektif Undang-Undang Perkawinan Dan KUHPerdata, Jurnal Penelitian Hukum DE JURE, Vol. 17 No. 4

[4] Firman Hidayat, Akhmad Khisni, Tinjauan Asas Kepastian Hukum, Keadilan, Dan Kemanfaatan Dalam Akta Perjanjian Kawin Yang Di Buat Oleh Notaris, Vol. 4 No. 4 December 2017, Jurnal Akta Unissula

[5] Nabilla Ayu Suraya, Akhmad Khisni and Munsharif Abdul Chalim, Research on Inheritance for Children from Sirri Marriage Based on the 
Compilation of Islamic Law, Volume 2 No. 4, December 2020, Jurnal Sultan Agung Notary Law Review

[6] Sukardi, 2016, "Kajian Yuridis Perjanjian Perkawinan Menurut Kitab Undang-Undang Hukum Perdata, Undang-Undang Nomor 1 Tahun 1974 dan Kompilasi Hukum Islam", Jurnal Khatulistiwa - Journal of Islamic Studies, Vol. 6, No. 1

[7] Syarief Husien, Akhmad Khisni, Hukum Waris Islam Di Indonesia (Studi Perkembangan Hukum Kewarisan Dalam Kompilasi Hukum Islam Dan Praktek Di Pengadilan Agama ), Vol 5 No 1 March 2018, Jurnal Akta

[8] Wisda Rauyani Efa Rahmatika, Akhmad Khisni, Analisis Yuridis Atas Perjanjian Perkawinan Ditinjau Dari Undang-Undang No.1 Tahun 1974 Tentang Perkawinan Dan Implikasi Putusan MK NO.69/PUU-XIII/2015 Vol. 4 No. 3 September 2017, Jurnal AKta Unissula

Books:

[1] Ahmad Azhar Basyir, 2007, Hukum Perkawinan Islam, cetakan kesebelas, UII Press, Yogyakarta

[2] Ahmad Rofiq, 2003, Hukum Islam di Indonesia, cetakan keenam, Rajawali Pers, Jakarta

[3] Bambang Waluyo, 1996, Metode Penelitian Hukum, Sinar Grafika, Jakarta

[4] Hilman Hadikusuma, 1963, Hukum Perkawinan Adat, Alumni, Bandung

[5] _ 2007, Hukum Perkawinan Indonesia Menurut: Perundangan, Hukum Adat, Hukum Agama, Mandar Maju. Bandung

[6] J.C.T. Simorangkir, 1972, Kamus hukum: oleh J. C. T. Simorangkir, Rudy T. Erwin dan J. T. Prasetyo Madjapahit

[7] Soemiyati, 2007, Hukum Perkawinan Islam dan Undang-Undang Perkawinan, cetakan keenam, Liberty, Yogyakarta

[8] Sunaryati Hartono, 1994, Penelitian Hukum Indonesia Pada Akhir Abad ke-20, Alumni, Bandung

[9] Ulber Silalahi, 2009, Metode Penelitian Sosial, Refika Aditanam, Bandung 